PERAN FINTECH (FINANCIAL TECHNOLOGY) DALAM MENINGKATKAN DAYA SAING PRODUK DI UKM INDUSTRI ALAS KAKI CIBADUYUT KOTA BANDUNG

Yuyun Yuniarti

Universitas Pasundan Bandung

Email: yuniarti_y@yahoo.com

\title{
Erti Dinihayati
}

Universitas Pasundan Bandung

Email: ertidinihayati@unpas.ac.id

\begin{abstract}
Footwear business activities in Cibaduyut, Bandung City are supported by various factors, such as entrepreneurial spirit, facilities, marketing, raw material procurement and capital procurement. This research is a qualitative research with data analysis through triangulation. The purpose of this study is mainly to find out the role of Fintech as one of the financial institutions that support in the field of business capital, especially micro-businesses such as Cibaduyut footwear, one of SME in Bandung City. The results of the study show that the Cibaduyut footwear industry is greatly helped by the existence of this Fintech although in the implementation still faces several obstacles, especially those concerning the knowledge and facilities to support these activities.
\end{abstract}

Keywords : Financial Technology, Product Competitiveness.

\section{LATAR BELAKANG}

Teknologi keuangan (Financial Technology) atau disebut fintech sebenarnya bukan pengembangan baru bagi industri jasa keuangan,meskipun demikian intensitas tentang kajian fintech sangat cepat. Isu tersebut juga menjadi perhatian banyak pihak di berbagai pelaku ekonomi baik di tingkat ekonomi makro maupun di tingkat ekonomi mikro.

Fintech menunjuk pada penggunaan teknologi untuk memberikan solusi-solusi keuangan secara spesifik. fintech didefinisikan sebagai aplikasi teknologi digital untuk masalah-masalah intermediasi keuangan. Definisi lain tentang fintech adalah industri yang terdiri dari perusahaan-perusahaan yang menggunakan teknologi agar sistem keuangan dan penyampaian layanan keuangan lebih efisien. (Hsueh,2017)

Evolusi fintech berawal dari inovasi kartu kredit pada tahun 1960-an. Kartu debit dan terminal yang menyediakan uang tunai seperti Anjungan Tunai Mandiri (ATM) pada tahun 1970 kemudian disusul dengan munculnya telepon banking dengan perubahan ini nasabah tidak perlu lagi berhadap-hadapan dengan pihak Bank.

Seiring dengan cepatnya penggunaan teknologi internet, perkembangan fintech juga merambah ke kegiatan industri besar, industri menengah dan industri kecil. Karena salah 
satu tujuan fintech adalah tercipta ekosistem ekonomi yang sehat untuk mendukung pertumbuhan ekonomi nasional yang berkelanjutan dengan tetap menjaga stabilitas moneter, stabilitas sistem keuangan serta sistem pembayaran yang efisien la dan lancar

Industri kecil dan menengah mempunyai peran yang sangat penting di dalam pembangunan dan pertumbuhan ekonomi, tidak hanya di negara-negara yang berkembang seperti Indonesia, tetapi juga di negara-negara maju seperti Jepang, Amerika Serikat dan Negara-negara di Eropa. Beberapa seminar dan lokakarya menyatakan bahwa UMKM di Indonesia sangat penting sebagai sumber pertumbuhan, kesempatan kerja dan meningkatkan pendapatan penduduknya.

Fintech dalam perkembangan UMKM memiliki dampat terhadap labour (tenaga kerja) yaitu dengan membantu Usaha Mikro Kecil dan Menengah (UMKM) serta individu yang belum terjangkau oleh Bank, dan mendorong penurunan biaya produksi sehingga menjadi lebih efisien dan dapat menjangkau lebih banyak konsumen. Dalam menghadapi pasar yang bersifat global perusahaan-perusahaan di Indonesia dituntut untuk masuk dalam organisasi perusahaan yang bersifat global seperti WTO (Word Trade Organization) GATT (General Agreement Tarif and Trade) AFTA (Asean Tree Trade Area) dan ACFTA (Asean China Free Trade Area ), dengan adanya kegiatan di bidang financial technology kegiatan bisnis global akan terdongkrak dan berdaya saing baik dari segi pengadaan bahan baku, pengelolaan marketing maupun pengadaan modal atau keuangan perusahaan.

Persaingan yang ketat antar perusahaan ataupun UMKM menyebabkan era ekonomi global perusahaan dituntut untuk mampu bersaing dalam kancah tantangan ekonomi global baru, dimana begitu pentingnya mengarah kepada sumber daya berbasis pengetahuan dan teknologi sebagai faktor utama dalam mempertahankan keunggulan bersaing bagi perusahaan (Kiong dan Lean, 2009) hal ini senada dengan pendapat AlMusali dan Ku Ismail (2012) yang menyatakan bahwa munculnya ekonomi berbasis pengetahuan dan teknologi menjadi faktor utama dalam menciptakan nilai perusahaan dan mempertahankan keunggulan bersaing. Munculnya New Economy yang secara prinsip didorong oleh perkembangan teknologi informasi dan ilmu pengetahuan juga telah memicu timbulnya kegiatan ekonomi financial technology (Petty dan Guthrie, 2000: Bontis 2001).

Kawasan Industri sepatu Cibaduyut merupakan salah satu sentra industri UMKM kota Bandung yang cukup terkenal, sentra kawasan sepatu Cibaduyut ini tidak kalah saing dengan produk sepatu luar negeri ,karena banyak penggemar sepatu lokal ini dari segmen anak muda hingga orang tua, data terakhir dari sub unit pengembangan industri kecil menengah Persepatuan Cibaduyut terdapat 577 unit usaha yang memproduksi berbagai jenis alas kaki seperti: sepatu pria, sepatu wanita, sepatu pantovel, sandal, sepatu olahraga, sepatu anak dan lain lain

Kapasitas produksi setiap tahunnya mencapai 3.114.022 pasang dengan nilai investasi sebesar 19 milyar rupiah. Tenaga kerja yang diserap 3008 jiwa yang terdapat di kawasan sentra sepatu ini (sumber: sub unit pengembangan industri kecil menengah persepatuan Cibaduyut, Dinas Perindustrian dan Perdagangan Provinsi Jawa Barat). 
Dampak adanya kegiatan industri sepatu Cibaduyut Kota Bandung telah berdirinya beberapa sektor industri lainnya seperti berdirinya toko-toko sepatu outlet bahkan pertokoan sepatu terpanjang di dunia, selain itu berdirinya toko-toko oleh khas kota Bandung seperti kuliner, boneka dan lain-lain.

Dalam menjalankan kegiatan usahanya para pelaku usaha UMKM alas kaki Cibaduyut menghadapi beberapa kendala seperti masalah pengadaan bahan baku, masalah pemasaran, masalah pengelolaan tenaga kerja dan terutama masalah pengdaan dana atau modal baik yang bersifat tradisional maupun yang bersifat modern atau dikenal dengan penggunaan fincial technologi (fintech).

\section{TINJAUAN PUSTAKA}

\section{Financial Technology (Fintech)}

Berdasarkan Pribadiono, hukum Esan dan Barat (2016), Financial Technology (Fintech) merupakan perpaduan antara teknologi dan fitur keuangan, selain itu dapat juga diartikan sebagai inovasi pada sektor finansial dengan sentuhan teknologi modern. Berdasarkan Dorfeitner, Hornuf, Schmitt, \& Webber (2017). Fintech merupakan industri yang bergerak dengan sangat cepat dan dinamis dimana terdapat banyak model bisnis yang berbeda. Hsueh (2017) juga menjelaskan bahwa teknologi keuangan merupakan model layanan keuangan baru yang dikembangkan melalui inovasi teknologi.

Berdasarkan uraian di atas maka peneliti medefinisikan fintech merupakan layanan di bidang keuangan yang didukung oleh sektor pengetahuan, fasilitas dan inovasi dari layanan tersebut. Hseuh berpendapat bahwa secara garis besar ada 3 tipe Fintech yaitu :

1. Sistem pembayaran melalui pihak ketiga (Third party payment system) yaitu contoh-contoh sistem pembayaran melalui pihak ketiga yaitu cross border EC, On line of line $\mathrm{O} 2 \mathrm{O}$, sistem pembayaran mobile, dan platform pembayaran yang menyediakan jasa seperti pembayaran bank dan transfer

2. Peer to Peer Lending.

Peer to Peer Lending merupakan platform yang mempertemukan pemberi pinjaman dan peminjam melalui internet. Peer to Peer Lending menyediakan mekanisme kredit dan manajemen risiko. Platform ini membantu pemberi pinjaman dan peminjam memenuhi kebutuhan masing-masing dan menghasilkan penggunaan uang secara efisien

\section{Crowdfounding}

Crowdfounding merupakan tipe fintech dimana sebuah konsep atau produk seperti desain, program, konten dan karya kreatif dipublikasikan secara umum dan bagi masyarakatan yang tertarik dan ingin mendukung konsep atau produk tersebut dapat memberikan dukungan secara finansial. Crouwdfounding dapat digunakan untuk mengurangi kebutuhan finansial, kewirausahaan, dan memprediksi permintaan pasar. 
Yuyun Yuniarti, Erti Dinihayati | Peran FINTECH (Financial Technology) dalam Meningkatkan ...

Menurut Otoritas Jasa Keuangan (OJK) (2016) kelebihan fintech adalah:

1. Melayani masyarakat Indonesia yang belum dapat dilayani oleh industri keuangan tradisional dikarenakan ketatnya peraturan perbankan dan adanya keterbatasan industri perbankan tradisional dalam melayan masyarakat di daerah tertentu.

2. Menjadi alternatif pendanaan selain jasa industri keuangan tradisional dimana masyarakat memerlukan alternatif pembiayaan yang lebih demokratis dan transparan.

Fintech merupakan pihak yang tidak memiliki lisensi untuk memindahkan dana dan kurang mapan dalam menjalankan usahanya dengan modal yang besar,jika dibandingkan dengan bank. Ada sebagian perusahaan Fintech belum memiliki kantor fisik, dan kurangnya pengalaman dalam menjalankan prosedur terkait sistem keamanan dan integritas produknya.

Menurut Otoritas Jasa Keuangan (2016) ada beberapa tantangan yang dihadapi dalam pelaksanaan kegiatan fintech, tantangan tersebut adalah :

1. Peraturan dalam mendukung pengembangan fintech. Adopsi peraturan terkait tanda tangan (digital signature) dan peggunaan dokumen secara digital sehingga dapat mengoptimalkan potensi yang dimiliki Fintech.

2. Koordinasi antar lembaga dan kementrian terkait untuk mengoptimalkan potensi Fintech dengan lingkungan bisnis (business environment) yang kompleks, maka perlu juga dukungan dari berbagai kemetrian dan lembaga terkait.

Menurut Otoritas Jasa Keuangan (2016), resiko yang dialami oleh pengguna fintech banyak sekali untuk itu diperlukan beberapa strategi untuk melindungi konsumen dan kepentingan nasional khususnya masyarakat pengusaha baik kecil kecil,menengah maupun besar.

Strategi untuk melindungi konsumen adalah sebagai berikut:

a. Perlindungan dana pengguna

Potensi kehilangan maupun penurunan kemampuan finansial, baik yang diakibatkan oleh penyalahgunaan, penipuan maupun force majeur dari kegiatan fintech.

b. Perlindungan data pengguna

Isu privasi pengguna fintech yang rawan terhadap penyalahgunaan data baik yang disengaja maupun yang tidak disengaja (serangan hacker atau malware.

Strategi untuk melindungi kepentingan nasional:

1. Anti pencucian uang atau dan pencegahan pendanaan terorisme (APU-PPT) kemudahan dan kecepatan yang ditawarkan oleh fintech menimbulkan potensi penyalahguaan untuk kegiatan pencucian uang maupun pendanaan terorisme.

2. Stabilitas Sistem Keuangan

Perlu manajemen risiko yang memadai agar tidak berdampak negatif terhadap stabilitas sistem keuangan. 


\section{Daya Saing (Competitive Advantage) UMKM}

Daya saing dari perusahaan dapat ditentukan oleh banyak faktor, tujuh diantaranya yang sangat penting adalah: keahlian atau tingkat pendidikan pekerja, keahlian pengusaha, ketersediaan modal, sistem organisasi dan manajemen yang baik (sesuai kebutuhan bisnis), ketersediaan teknologi, ketersediaan informasi, dan ketersediaan input-input lainnya seperti energi, dan bahan baku.

Selain teori di atas, teori lain tentang daya saing dan paling sesuai dengan konsep daya saing dikemukakan oleh Porter (1993 ) yang dikenal dengan teori NCA dengan berbagai faktor Daya saingnya yaitu:

\section{Factor Condition}

Faktor yang mengacu pada input yang digunakan sebagai faktor produksi seperti tenaga kerja,sumber daya alam, modal dan infra struktur

\section{Demand Condition}

Faktor yang mengacu pada tersedianya pasar domestik yang siap berperan menjadi elemen penting dalam menghasilkan daya saing.

\section{3. $\quad$ Related and Supporting Industries}

Faktor yang mengacu pada tersedianya serangkaian dan adanya keterkaitan kuat antara industri pendukung dan perusahaan, hubungan dan dukungan ini bersifat positif yang berujung pada peningkatan daya saing perusahaan.

4. Firm Strategy, Structure and Rivalry

Faktor yang mengacu pada strategi dan struktur yang ada pada sebagian perusahaan dan intensitas persaingan pada industri tertentu.Faktor strategi an Pasar modal domestik mempengaruhi strategi perusahaan,sementara individu seringkali membuat keputusan karir berdasarkan peluangn dan prestise.

Hubeis (2009: 4) menyatakan bahwa permasalahan UMK di Indonesia dapat dikelompokkan dalam tiga kategori, yaitu:

a. Permasalahan klasikdan mendasar, misalnya: keterbatasan modal, SDM, pengembangan produk, dan akses pemasaran.

b. Permasalahan pada umumnya, misalnya antara peran dan fungsi instansi terkait dalam menyelesaikan masalah dasar yang berhubungan dengan masalah lanjutan, seperti prosedur perijinan, perpajakan, agunan, dan hukum.

c. Permasalahan lanjutan, misalnya pengenalan dan penetrasi pasar ekspor yang belum optimal, kurangnya pemahaman desain produk yang sesuai dengan karakter pasar, permasalahan hukum yang menyangkut perijinan, hak paten dan prosedur kontrak.

\section{METODE PENELITIAN}

\section{Desain Penelitian}

Pendekatan yang dilakukan dalam penelitian ini adalah pendekatan kualitatif, yaitu penelitian yang dilakukan secara induktif untuk memperoleh data yang bersifat 
menyeluruh atau holistic dan mendalam. Sealin itu desain penelitian ini bersifat terbuka artinya dalam kurun waktu tertentu dijumpai aspek yang penting yang harus dicakup dalam penelitian,meskipun tidak terduga sebelumnya.

\section{Teknik Pengumpulan Data}

Teknik pengumpulan data menggunakan :

a. Dokumentasi, yaitu penelitian melakukan pengumpulan data dengan menggunakan literatur baik berasal dari buku maupun artikel.

b. Observasi, yaitu teknik pengumpulan data dengan melakukan pengamatan dan pencatatan secara langsung pada objek yang diteliti. Observasi dilakukan dengan mengamati kegiatan di produsen sepatu Cibaduyut Kota Bandung mulai dari desain produk,penentuan bahan baku, pencetakan Shoelast pemotongan bahn, penjahitan kulit sepatu dan pengeleman Sole dengan kulit serta pemasaran dan pedistribusian produk sepatu.

c. Wawancara mendalam melalui tanya jawab dan dialog dengan pihak yang berkepentingan /berwenang dari institusi atau perusahaan yang terkait, untuk mendapatkan gambaran umum mengenaikegiatan pembuatan sepatu atau alas kaki di Cibaduyut Kota Bandung. Disamping itu penelitian ini juga mendapat bantuan dari beberapa informa yang membantu memberikan informasi yang akurat terutama yang menyangkut kegiatan pelaksanaan dan pernanan fintech yang berhubungan dengan kegiatan daya saing produk sepatu Cibaduyut dibandingkan dengan produk sepatu yang datang dari luar atau produk impor terutama produk sepatu dari Cina.

\section{Teknik Analisis Data}

Analisis data pada penelitian ini mengacu pada model analisis data kualitatif dari Miles dan Huberman. Yang dikutip Sugiono (2011: 91) analisis data melalui tiga langkah yaitu:

\section{Data Reduction}

Reduksi data yaitu kegiatan merangkum, memilih hal-hal pokok memfokuskan pada hal-hal penting dicari tema dan polanya, sehingga data yang direduksi akan memberikan gambaran yang lebih jelas dan mempermudah peneliti untuk melakukan pengumpulan data sebelumnya dan ditindak lanjuti di kemudian hari.

2. Data Display (penyajian data)

Setelah data direduksi langkah selanjutnya adalah menyajikan data tersebut untuk mempermudah dalam memahami apa yang terjadi dan merencanakan kerja selanjutnya berdasarkan apa yang telah dipahami tersebut. dalam penelitian kualitaif penyajian data bisa berupa tabel, grafik, flowchart atau bentuk naratif. 
3. Conclusing drawing (verifikakasi data) atau menarik kesimpulan

Kesimpulan awal yang dilakukan masih bersifat sementara dan perlu dibuktikan dengan data-data yang mendukung terhadap kesimpulan sebelumnya sehingga bisa memperkuat hasil penelitian

4. Triangulasi Data

Pengujian kredibilitas data penelitian menggunakan triangulasi teknik dan sumber data. Triangulasi teknik menggunakan cara dengan menanyakan hal yang sama dengan teknik yang berbeda. Yaitu dengan cara menenyakan hal yang sama melalui observasi, wawancara dan dokumentasi.

5. Diskusi

Hasil penelitian didiskusikan dengan tim peneliti dan objek penelitian serta instansi yang terkait dengan kegiatan penelitian, untuk mendapatkan masukan, pertanyaan berkenaan dengan data yang didapatkan sehingga data yang didaptkan akan lebih lengkap dan kredibel.

\section{HASIL DAN PEMBAHASAN}

Sebagai sentra kerajinan sepatu yang dimulai tahun 1920 dimana sebagian warga setempat merupakan pekerja pada pabrik sepatu di Bandung, namun akhirnya mereka memutuskan untuk berhenti bekerja di pabrik tersebut. Berbekal pengalaman mereka bekerja pada pabrik sepatu mereka merintis usaha pembuatan dan penjualan produk alas kaki sederhana di lingkungan rumah dengan melibatkan anggota keluarga sebagai tenaga kerjanya.

Dalam melakukan kegiatan alas kaki para pengrajin menghadapi beberapa kendala baik itu yang bersifat eksternal maupun internal. Kendala yang bersifat eksternal misalnya terbatasnya pengetahuan desain, alat produksi yang masih sederhana, dan pemasaran serta pengadaan modal yang masih tradisional. Kendala yang bersifat internal misalnya dalam hal pengadaan dan pengelolaan karyawan, dan jiwa kewirausahaan dari pelaku usaha itu sendiri.

Seiring perkembangan zaman, di era milenial ini para pelaku usaha industri alas kaki Cibaduyut juga harus mengikuti kondisi kegiatan usaha di masa kini atau dengan istilah zaman now. Dampak penggunaan teknologi informasi terutama internet mendorong para pelaku usaha alas kaki untuk menambah ilmu pengetahuan, keterampilan dan wawasan di berbagai bidang terutama di pengelolaan keuangan uyang menggunakan teknologi.

Dalam memahami financial technology para pelaku usaha alas kaki dituntut untuk hati-hati dan waspada supaya dalam menerapkan pengadaan teknologi ini benarbenar bermanfaat dan memberikan solusi kepada pelaku usaha alas kaki Cibaduyut Kota Bandung. Berdasarkan hasil penelitian di bidang fintech yang berparan dalam meningkatkan daya saing produk dengan produk dari Cina maka peneliti mendapatkan hasil penelitian sebagai berikut: 
1. Pembayaran melalui pihak ketiga

Kegiatan UMKM secara umum tidak bisa berdiri sendiri tetapi ditunjang oleh faktorfaktor lain, demikian pula para pengrajin alas kaki Cibaduyut kota Bandung dalam melakukan kegiatan usahanya ditunjang oleh pihak lain mulai dari pengadaan bahan baku, pengolahan kulit sepatu sampai pemasaran dan hubungan dengan pihak lain. Jika dilihat dari tujuh faktor daya saing UMKM ternyata adalah adanya kerjasama di bidang keuangan. Para pelaku usaha dalam pengadaan modalnya tidak bisa mengandalkan modal sendiri, tetapi dibantu oleh pihak lain. Pengadaan modal usaha bisa didapat melalui pinjaman dari bank, pinjaman dari koperasi, atau bantuan pinjaman dari lembaga lain.

Peran fintech di kegiatan usaha alas`kaki Cibaduyut Kota Bandung sudah diterapkan meskipun hanya baru beberapa pengrajin yang sudah memakai fasilitas Fintech. Penggunaan fintech digunakan jika para pengrajin (UKM) sudah dalam keadaan "kepepet" atau pada saat situasi ada orderan (pesanan) dadakan yang membutuhkan penyelesaian pesanan yang cepat selesai sehingga pengrajin tidak perlu lagi meminjam ke pihak lain seperti rentenir.

Dalam pengelolaannya dana fintech tersebut oleh para pengrajin digunakan sebaik mungkin meskipun masih banyak kendala yang dihadapi seperti tingkat suku bunga yang tinggi. Hal ini berdampak pada harga jual produk yang mahal akibatnya harga jualnya tinggi, akibatnya produk tersebut tidak bisa bersaing dengan produk luar terutama dengan produk sepatu dari Cina yang harganya lebih murah dibandingkan dari Cina.

Peranan pihak lain dalam penggunaan fintech di UKM Cibaduyut Kota Bandung sangat besar, bisa dilihat dari mulai promosi, pengelolaan dana usaha dan sampai dengan pengembalian Fintech tujuan lainnya dengan bantuan dana fintech produk sepatu Cibaduyut bisa bersaing di pasar global.

2. Peer to Peer Landing (mempertemukan pemberi pinjaman dan peminjam melalui internet)

Pemakaian internet di UKM bukan saja sebagai media pemasaran seperti pemasaran online, tetapi juga menjadi inspirasi bisnis baik untuk anak muda maupun ibu-ibu rumah tangga untuk mau berbisnis karena melihat pasar menjadi terbuka luas dengan adanya internet, misalnya dengan bergabungnya seseorang dalam facebook atau instagram yang asalnya tidak mau usaha menjadi tertarik menjdi pebisnis. Jadi internet di kalangan pengusaha merupakan bentuk kepercayaan diri mulai dari penentuan produk yang akan dibuat, pengolahan sampai ke pemasaran serta pengelolaan keuangan.

Dalam pengelolaan masalah pinjaman para pelaku usaha telah terhubung atau terkoneksi secara cepat melalui internet. Berdasarkan hasil pengamatan proses peminjamann modal melalui fintech prosesnya sangat cepat,mudah dan tidak perlu adanya agunan sehingga kedua belah pihak saling diuntungkan dan dipertemukan kegiatan usahanya melalui internet yang dapat mencptakan produk sepatu yang berdaya saing. 


\section{Counfaundings}

Keberadaan fintech juga berperan dalam mendesain kegiatan perusahaan. Produk alas kaki yang punya desain sesuai dengan selera konsumen merupakan produk yang berdaya saing. Desain produk dibuat sedemikian rupa sesuai dengan selera konsumen bahkan model yang Up to Date yang diinginkan oleh konsumen. Menciptakan produk sepatu yang sesuai selera konsumen memerlukan biaya yang tinggi maka dalam kondisi tersebut fintech membantu pembiayaan secara cepat dan tepat sehingga menghasilkan produk sepatu yang berdaya saing tinggi didukung oleh faktor daya saing kemampuan tenaga kerja yang terampil dan punya skill yang sesuai dengan kebutuhan perusahaan.

Jiwa kewirausahaan para pelaku usaha alas kaki Cibaduyut Kota Bandung terus dipupuk agar para pengusaha tidak merasa jenuh / bosan maka dengan peran fintech ini diharapkan meningkatkan motivasi para pengusaha untuk terus berinovasi melalui fintech dengan segala kemudahannya sehingga menghasilkan produk yang berinovasi dan berdaya saing global.

\section{KESIMPULAN}

Berdasarkan hasil penelitian dan pembahasan serta analisis data di atas maka penulis menyimpulkan bahwa:

1. Peran fintech dalam menunjang kegiatan usaha produk alas kaki Cibauyut Kota bandung sangat besar sehingga peran fintech tersebut dapat meningkatkan daya saing produk.

2. Belum semuanya pelaku usaha alas kaki menggunakan fasiliatas ini karena keterbatasan fasilitas dan teknologi.

3. Peran Fintech diperlukan dalam menunjang pertumbuhan usaha di berbagai kegiatan usaha.

\section{SARAN-SARAN}

1. Sebaiknya para pelaku usaha memanfaatkan peran fintech dalam kegiatan usahanya sebagai penunjang pengembangan kegiatan usaha di masa yang akan datang

2. Sebaiknya pemerintah lebih melindungi kedua belah pihak yaitu pihak pelaku usaha dan pengelola fintech supaya jika terjadi hal-hal yang tidak diinginkan sudah berada dalam payung hukum yang saling menguntungkan.

\section{DAFTAR PUSTAKA}

\section{A. Buku}

Ardela, Fransiska. (2017). Perkembangan Fintech di Indonesia. (https://www.finansialku. com/perkembanga n-fintech-di-indonesia/ , diakses 13 Juli 2018) 
Yuyun Yuniarti, Erti Dinihayati | Peran FINTECH (Financial Technology) dalam Meningkatkan ...

Hsueh, S. C., Kuo C. H. (2017). Effective Matching for P2P Lending by Mining Strong Association Rules. Proceedings of the 3rd International Conference on Industrial and Business Engineering p 30-33.

Musa Hubeis, Mukhamad Najib (2013). Manajemen Strategik Dalam Pengembangan Daya Saing Organisasi Penerbit Elex Media Komputindo

\section{B. Dokumen-dokumen:}

Sub Unit Pengembangan Industri Kecil Menengah Persepatuan Cibaduyut. Dinas Perindustrian dan Perdagangan Provinsi Jawa Barat.

Peraturan Menteri Perindustrian Nomor 123/M-IND/PER/110/2010 tentang rogram Revitalisasi dan pertumbuhan industri alas kaki.

Undang-Undang Nomor 20 Tahun 2008 tentang UMKM 